\title{
Oocyte distribution within and between ovary lobes is largely homogeneous in Lachnolaimus maximus (Perciformes: Labridae)
}

\author{
Virginia Elena Nóh Quiñones ${ }^{1}$, J. René Torres-Villegas², Thierry Brulé1, Jorge L. Montero-
} Muñoz $^{1} \&$ Uriel Fernando Valdez-Montiel ${ }^{2}$

1. Centro de Investigación y de Estudios Avanzados del Instituto Politécnico Nacional, Departamento de Recursos del Mar, Unidad Mérida, Ant. Carr. a Progreso Km. 6, A.P. 73 Cordemex, 97310 Mérida, Yucatán, México; vicky_01_3@hotmail.com, tbrule@cinvestav.mx, jorge.montero@cinvestav.mx

2. Centro Interdisciplinario de Ciencias Marinas del Instituto Politécnico Nacional, Departamento de Pesquerías y Biología Marina, Av. Instituto Politécnico Nacional s/n, Col. Playa Palo de Santa Rita, 23096 La Paz, Baja California Sur, México; jrtorresv@gmail.com,urielfernandovaldez@gmail.com

Received 02-II-2016. C Corrected 12-VII-2016. Accepted 11-VIII-2016.

\begin{abstract}
In fish reproduction, previous information of ovary oocyte distribution is necessary, when oocytes quantitative estimates are required to estimate batch or annual fecundity. Heterogeneous oocyte distribution requires a standardized sampling protocol to prevent bias in estimates, whereas homogeneous distribution, allows sampling of any portion of gonads with no risk of bias. We studied gonad oocyte distribution patterns in the hogfish Lachnolaimus maximus population from Southern Gulf of Mexico. For this, 23 mature females were selected from a total of 47 individuals exhibiting visible oocytes in the ovaries. These females were classified by reproductive phase and sub-phase (early developing-ED, developing-D, spawning capable-SC and actively spawning-AS). Six histological sections were taken from the anterior, middle and posterior regions of the left and right ovary lobes of each individual. Digital image processing (AxioVision and Image ProPlus programs) was used to estimate oocyte density per unit area, and for different development stages. Contingency tables were used to analyze oocyte distribution frequencies between the regions of each lobe, and between the lobes of each ovary. This was supported with a Pearson's $\chi^{2}$ test for goodness-of-fit and a replicated G test to confirm distribution heterogeneity. Oocyte stage distribution was homogeneous in almost all 23 females regardless of the ovary lobe. In the left ovary lobe, oocyte distribution was uniform in all three regions sampled regardless the female phase or sub-phase. In the right ovary lobe, oocyte frequencies were similarly uniform for the ED, D and AS phase and sub-phases; nevertheless, during SC phase, some heterogeneity was observed in tertiary vitellogenesis- $\operatorname{Vtg} 3$ oocytes, especially in samples from middle and posterior regions of this lobe. Females in AS sub-phase are normally used to estimate batch fecundity in fish such as L. maximus, which has shown to have asynchronous oocyte development and batch spawning. Given the homogeneous oocyte distribution pattern within and between the ovary lobes in females in AS sub-phase, no systematization is required of the gonad histological sampling protocol to estimate species batch fecundity. Nevertheless, due to the heterogeneous Vtg3 oocytes distribution in the right ovary lobe of females in the SC phase, it is best to systematically take sections of any region in the left ovary lobe when conducting a study encompassing all of a species' reproductive aspects. Rev. Biol. Trop. 65 (1): 293-303. Epub 2017 March 01.
\end{abstract}

Key words: reproduction, ovarian homogeneity, hogfish, Gulf of Mexico.

Reproduction has direct implications in the exploitation, management and cultivation of fishes (Wootton \& Smith, 2015). Fish reproduction studies involving microscopic observation of gonads require preliminary analyses of oocyte distribution homogeneity in females at different ovary development stages. During maturation, fish ovaries undergo voluminous development. For practical reasons, histological observations of large ovaries are normally done using randomly sampled areas within a section of one of the ovary's two lobes. Quantitative 
analysis of the structure of any biological tissue using histological sections requires basic data on cell type distribution in the studied organ. If distribution of the different oocytes stages is homogeneous within the gonad during a fish species' reproductive season, samples can be collected from any region of either lobes, and will be representative of the female's degree of maturity (e.g. Ma, Kjesbu, \& Jirgensen, 1998; Witthames et al., 2009; McElroy, Wuenschel, Press, Towle, \& McBride, 2013). On the other hand, if distribution among the different regions of a lobe or between the two lobes is heterogeneous, a systematic protocol is required for collecting samples for histological analysis (Witthames \& Greer Walker, 1995; Nichol \& Acuna, 2001; Kennedy, Witthames, \& Nash, 2007; Hainfellner, de Souza, Nascimento, Freitas, \& Batlouni, 2011). Generally, a lack of a standardized ovary sample collection method, may create significant bias in data for fecundity estimations (Murua et al., 2003).

A number of fish reproduction studies have addressed oocyte distribution pattern in the ovary. Most of these studies have focused on a species' reproductive biology, defining spawning season, and characterizing sexual differentiation and gonad development. To identify the homogeneity degree in ovary oogenesis, analyses have been commonly done along three regions (anterior, middle and posterior) of each ovary lobe (right and left). Generally, three parameters have been used in most of these studies: average oocyte diameter, oocyte density per unit of weight; and oocyte density per unit of ovary tissue surface. Studies have addressed females in different maturation phases and all oocyte stages present in the ovary (Tricas \& Hiramoto, 1989; Lee, Liu, Su, \& Wu, 2005; Weng, Liu, Lee, \& Tsai, 2005; Hainfellner et al., 2011; Liao \& Chang, 2011, Wu, Su, Liu, Weng, \& Wu, 2012), as well as only vitellogenic or mature oocytes (Witthames \& Greer Walker, 1995; Ma et al., 1998; Nichol \& Acuna, 2001; McElroy et al., 2013). Some do not include exact data on female maturation phases and/or the oocyte stages analyzed (Matić-Skoko, Kraljević, \& Dulčić,
2004; Kennedy et al., 2007; Reñones, Grau, Mas, Riera, \& Saborido-Rey, 2010; Sequeira, Neves, Paiva, Vieira, \& Gordo, 2012; Yang, Chen, \& Hu, 2013).

Gonadal development studies have focused in standard histological methods, and very few studies have used digital image analysis, to calculate average oocyte diameter and estimate oocyte density (Nichol \& Acuna, 2001; McElroy et al., 2013); although this type of analysis has been in use in the biological sciences for over a decade (Klibansky \& Juanes, 2008). The application of digital image processing techniques may generate data on structure from images normally intended to improve image quality and in the search of data (Pertusa, 2003). They can also be used to count and measure cells or other small particles in an image, and to make precise measurements; besides, the use of these techniques has reduced the processing time, health risks and costs of standard histological methods.

Hogfish Lachnolaimus maximus (Walbaum, 1792) is a labrid fish species distributed from the mid-Atlantic seaboard of the United States (North Carolina) to the North coast of South America (Venezuela and Guyana), including the Bermudas, the Gulf of Mexico and the Caribbean Sea (Carpenter, 2002). It is important in commercial and recreational fisheries throughout its range, and presently, the IUCN (2016) has considered the species to be at high risk of extinction in the wild (Vulnerable A2bd). Growth and recruitment stage overfishing has been reported in a $L$. maximus population in South Florida (US) (McBride \& Murphy, 2003; McBride \& Richardson, 2007; McBride, Thurman, \& Bullock, 2008). The L. maximus population in Southern Gulf of Mexico, on the continental shelf of the Yucatan Peninsula (known as Campeche Bank), is considered a high value alternative target fishing resource. To date, no studies have been done on the biology, exploitation level and conservation status of $L$. maximus population in Campeche Bank.

The reproductive biology of this species' has been studied in populations of Puerto Rico 
(Colin, 1982), Cuba (Claro, García-Cagide, \& Fernández de Alaiza, 1989), North Carolina (Parker, 2000), the Northeast Gulf of Mexico, and South Florida (Davis, 1976; McBride, Johnson, Bullock, \& Stengard, 2001; Robinson \& Prince, 2003; McBride \& Johnson, 2007; McBride et al., 2008; Muñoz, Burton, Brennan, \& Parker, 2010; Collins \& McBride, 2015). Of these studies, six have included histological analysis of gonads to identify species sexuality (protogynous hermaphrodite) and reproductive cycle, and to estimate fecundity. Only two (Davis, 1976; McBride \& Johnson, 2007) have addressed spatial development of oocytes in the ovaries. Neither of these reported studies have evidence of heterogeneous oocyte development between lobes or within sections of the same lobe. But Davis (1976) only analyzed two females, while McBride and Johnson (2007) made a cursory examination of a small number of slides (3 locations) from a limited number of females $(n=14)$ to ensure that no clear difference in oocyte distribution patterns occurred between locations (McBride, personal communication, May 19, 2016).

The objective of the present study was to characterize oocyte distribution patterns in different developmental stages and different sections of the ovary of L. maximus, by the use digital images taken from histological sections of female gonads, in different development stages. The resulting oocyte distribution patterns will determine the sampling protocol for histological sampling from gonads of this species, thus providing more accuracy to analyses of main reproductive parameters (i.e. maturity, reproductive cycle and fecundity) of $L$. maximus in Campeche Bank.

\section{MATERIALS AND METHODS}

Specimen collection: The data analyzed here were collected as part of a project studying L. maximus reproduction in Campeche Bank. Specimens were collected between May 2013 and January 2014 in three coastal marine zones, corresponding to areas reported to have substantial abundance of $L$. maximus along the coast of the state of Yucatán (MexicanoCíntora, Leonce-Valencia, Salas, \& Vega-Cendejas, 2007): Celestún (west zone: 2051'33" $\mathrm{N}$ - 90 24'0" W); Dzilam de Bravo (central zone: $21^{\circ} 23^{\prime} 33^{\prime \prime} \mathrm{N}-88^{\circ} 53^{\prime} 29^{\prime}$ " W); and Río Lagartos (East zone: $21^{\circ} 35^{\prime} 51^{\prime \prime} \mathrm{N}-88^{\circ} 9^{\prime} 28^{\prime \prime}$ $\mathrm{W})$. Specimens were caught between six and 22 $\mathrm{m}$ depth by professional fishers using harpoons and compressor diving gears. Sex identification was done based on sexual dimorphism traits described by Davis (1976), Claro et al. (1989) and McBride and Johnson (2007). For each specimen we recorded fork length (FL; nearest $0.1 \mathrm{~cm}$ ) with a graduated ictiometer and whole weight (WW; with an electric scale Sartorius model TE2101 with a $2100( \pm 0.1)$ g capacity). A total of 850 specimens were collected, of which 646 were female (size range: $13.9-39.4 \mathrm{~cm} \mathrm{FL;} 135-1132 \mathrm{~g} \mathrm{WW}$ ) and 204 were male (26.3-47.4 cm FL; 344-1 885 g WW). Based on previous data on its reproductive cycle of populations in Florida and Cuba (Davis, 1976; Claro et al., 1989; McBride et al., 2008; Collins \& McBride, 2015), the ninemonth collection period considered, included the probable maturation season of $L$. maximus in Campeche Bank.

Female selection and ovary histology: From the total sample of females, a preselection was made of those exhibiting visible oocytes in the ovaries $(\mathrm{N}=47 ; 20.2-35.3 \mathrm{~cm}$ FL; 171-939 g WW), taking care to identify mature adult individuals with secondary growth oocytes. Six samples were extracted from each preselected ovary for histological analysis: one from the anterior, middle and posterior sections of the left and right ovarian lobes. These were fixed in Bouin's solution for four to five days, embedded in paraplast, sectioned at a $6 \mu \mathrm{m}$ thickness (4 to five sections per sampled region), and stained with Gabe and Martoja's one-step trichrome stain (Gabe, 1968). Based on the histological analyses, the preselected females were classified by their gonad development phase into one of the following reproductive phases or sub-phases (Brown-Peterson, Wyansky, Saborido-Rey, 
Macewicz, \& Lowerre-Barbieri, 2011): early developing (ED), developing (D), spawning capable (SC) and actively spawning (AS).

The histological sections of only 23 females (20.3-34.0 cm FL; 191-814 g WW) were of sufficient quality (i.e. sections with no broken or incomplete oocyte and adequate color contrast) to allow digital image processing.

Image analysis: Digital images were taken from three microscopic fields (each field $=3.8 \mathrm{~mm}^{2}$ ) of each ovary region section using a camera (Axiocam MRc) attached to a microscope (Axioscop; 25X). Each image was analyzed with the Image-Pro Plus 6.0 program (Media Cybernetics, Inc.).

Before beginning the oocyte count, all oocytes (that did not appear complete in the right and upper portions of each field) were excluded to prevent recounting of the same oocyte. Each image was processed with spectral analysis and a binary mask generated within which the selected oocytes were counted. Oocyte stages were identified based on the criteria developed by Wallace and Selman (1981), Brown-Peterson, Thomas and Arnold (1988) and Lowerre-Barbieri et al. (2009): primary growth (PG) oocyte; cortical alveolar (CA) oocyte; primary, secondary and tertiary vitellogenic (Vtg1, 2 and 3, respectively) oocytes; and oocyte maturation (OM). The oocyte maturation stage included: germinal vesicle migration, germinal vesicle breakdown, yolk coalescence, and hydration events.

Contingency tables (rows x columns) were applied to each group of females which had been classified into the four reproductive phases or sub-phases to analyze the frequency distributions of oocyte stage (columns) at two levels (rows): 1) anterior, middle and posterior regions of each ovary lobe, and 2) right and left lobes of the ovary. A Pearson's Chisquared $\left(\chi^{2}\right)$ was used to determine if oocyte frequencies were uniform between rows and columns. When distributions were not uniform, a replicated goodness-of-fit test (heterogeneity G-test) (Sokal \& Rohlf, 1995) was applied to identify which rows differed in terms of oocyte frequency between columns. All statistical analyses $(\alpha=0.05)$ were run with the InfoStat program (Di Rienzo et al., 2013).

\section{RESULTS}

Following the degree of ovary development, the 23 selected females analyzed were classified in four reproductive phases or subphases: eight were in the ED sub-phase; four in the D phase; five in the SC phase; and six in the AS sub-phase (Fig. 1). The latter did not exhibit newly collapsed post-ovulatory follicles (POFs) in the ovary. The different oocyte stages characteristic of each female reproductive phases and sub-phases were observed in all the examined ovary sections and lobes (Table 1). In addition, the oocyte density typical of each phase and sub-phase was generally very similar between ovary regions and lobes; the one exception being Vtg3 oocytes in the right ovary of SC phase females.

The oocyte frequency analysis showed that the oocyte distribution was uniform in all three regions of the left lobe $\left(\chi^{2}, 0.1423 \leq \mathrm{P}\right.$ $\leq 0.3858$ ), no matter the phase or sub-phase (Table 2). In the right lobe, oocyte frequencies were also uniform in females at the ED subphase $\left(\chi^{2}, \mathrm{P}=0.2683\right)$, the $\mathrm{D}$ phase $\left(\chi^{2}, \mathrm{P}=\right.$ $0.4006)$ and the AS sub-phase $\left(\chi^{2}, \mathrm{P}=0.6852\right)$. However, females in the SC phase exhibited significant differences in oocyte frequencies in this lobe $\left(\chi^{2}, \mathrm{P}=0.0146\right)$. This discrepancy in frequencies in the SC phase females was confirmed by the $\mathrm{G}$ test $(\mathrm{P}=0.0086$; Table 3$)$. Significant differences were present between any combination of the three regions in the right lobe of these females, the highest being between the middle and posterior lobes. This difference was probably caused by variability in $\mathrm{Vtg} 3$ oocyte frequency between the three regions of the right lobe (Table 1). The SC phase females analyzed here were likely just entering that phase. Nonetheless, if this oocyte category is excluded from the statistical analysis, distribution of all the other oocyte categories (PG, CA, Vtg1 and 2 oocytes) was homogeneous throughout the three regions 


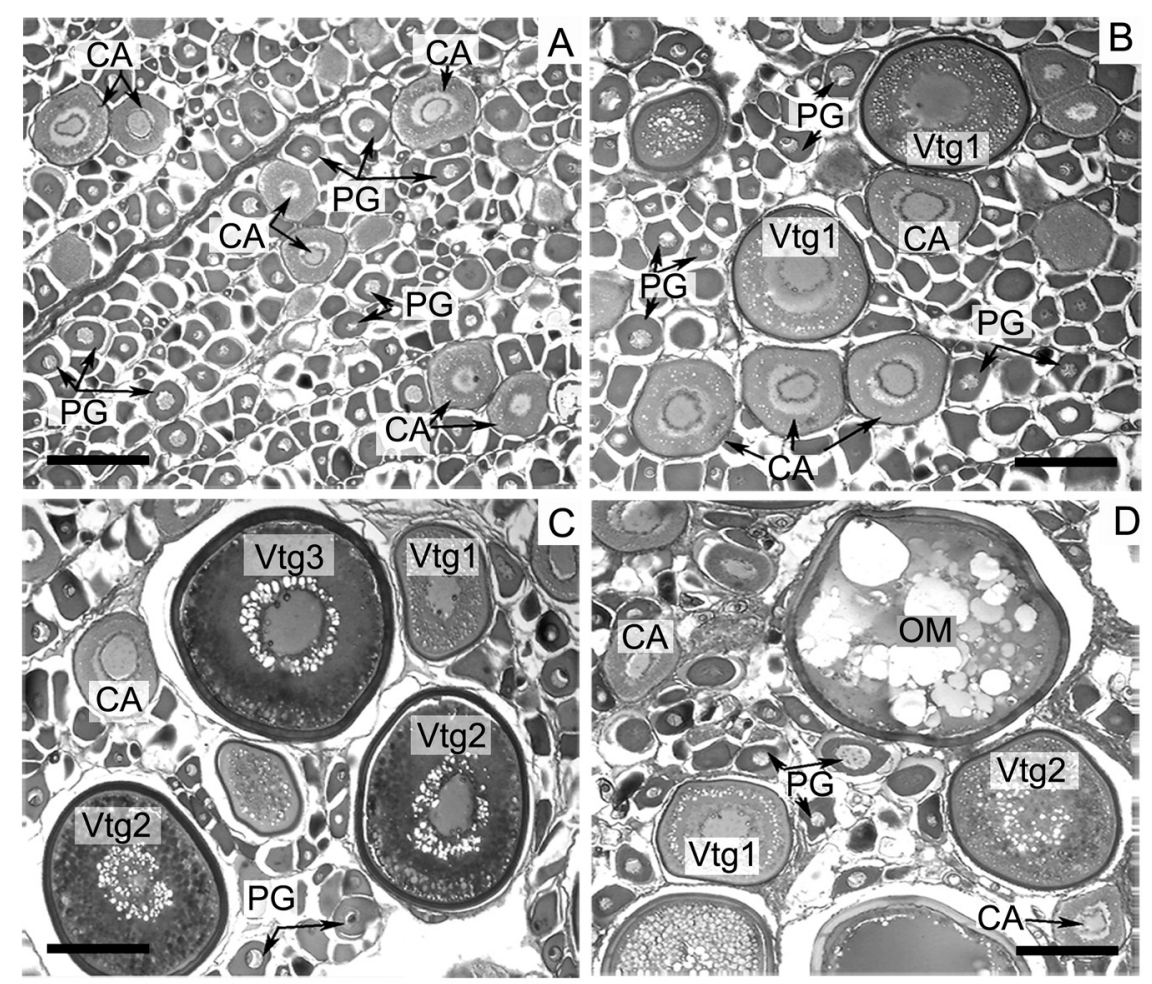

Fig. 1. Histological sections of ovaries from Lachnolaimus maximus collected on Campeche Bank (Gabe and Martoja's onestep trichrome stain; scale bar $=200$ microns). A) female in early developing reproductive sub-phase $(30.6 \mathrm{~cm} \mathrm{FL})$, collected 16 Oct. 2013; B) female in developing reproductive phase $(31.2 \mathrm{~cm} \mathrm{FL})$, collected 16 Oct. 2013; C) female in spawning capable reproductive sub-phase (27.8 cm FL), collected 15 Oct. 2013; and D) female in actively spawning reproductive sub-phase (20.6 cm FL), collected 22 May 2013. CA = cortical alveolar oocyte; $\mathrm{PG}=$ primary growth oocyte; $\mathrm{OM}=$ oocyte maturation (germinal vesicle breakdown and yolk coalescence); Vtg1 = primary vitellogenic oocyte; Vtg2 = secondary vitellogenic oocyte; $\operatorname{Vtg} 3=$ tertiary vitellogenic oocyte.

TABLE 1

Oocyte density (number per unit area) frequencies observed in anterior, middle and posterior regions of left and right ovary lobes of Lachnolaimus maximus females in different reproductive phases and sub-phases

\begin{tabular}{|c|c|c|c|c|c|c|c|c|c|}
\hline \multirow{2}{*}{$\begin{array}{c}\text { Female reproductive } \\
\text { phase }\end{array}$} & \multicolumn{2}{|c|}{ Ovary } & \multicolumn{6}{|c|}{ Total oocyte counts } & \multirow{2}{*}{$\begin{array}{l}\text { Total area analyzed } \\
\qquad\left(\mathrm{mm}^{2}\right)\end{array}$} \\
\hline & Lobe & Region & PG & $\mathrm{CA}$ & Vtg1 & $\mathrm{Vtg} 2$ & Vtg3 & $\mathrm{OM}$ & \\
\hline \multirow{6}{*}{$\begin{array}{l}\text { Early developing }{ }^{\mathrm{a}} \\
(\mathrm{n}=8)\end{array}$} & Left & A & 1833 & 321 & - & - & - & - & \multirow[t]{6}{*}{91.2} \\
\hline & & M & 1918 & 302 & - & - & - & - & \\
\hline & & $\mathrm{P}$ & 1815 & 336 & - & - & - & - & \\
\hline & Right & $\mathrm{A}$ & 1913 & 316 & - & - & - & - & \\
\hline & & M & 1833 & 283 & - & - & - & - & \\
\hline & & $\mathrm{P}$ & 1774 & 316 & - & - & - & - & \\
\hline \multirow{6}{*}{$\begin{array}{l}\text { Developing } \\
(\mathrm{n}=4)\end{array}$} & Left & A & 695 & 142 & 81 & - & - & - & \multirow[t]{6}{*}{45.6} \\
\hline & & M & 728 & 146 & 81 & - & - & - & \\
\hline & & $\mathrm{P}$ & 816 & 154 & 63 & - & - & - & \\
\hline & Right & $\mathrm{A}$ & 766 & 129 & 94 & - & - & - & \\
\hline & & M & 729 & 150 & 92 & - & - & - & \\
\hline & & $\mathrm{P}$ & 788 & 127 & 96 & - & - & - & \\
\hline
\end{tabular}


TABLE 1 (Continued)

\begin{tabular}{|c|c|c|c|c|c|c|c|c|c|}
\hline \multirow{2}{*}{$\begin{array}{l}\text { Female reproductive } \\
\text { phase }\end{array}$} & \multicolumn{2}{|c|}{ Ovary } & \multicolumn{6}{|c|}{ Total oocyte counts } & \multirow{2}{*}{$\begin{array}{l}\text { Total area analyzed } \\
\qquad\left(\mathrm{mm}^{2}\right)\end{array}$} \\
\hline & Lobe & Region & PG & $\mathrm{CA}$ & Vtg1 & Vtg2 & Vtg3 & $\mathrm{OM}$ & \\
\hline \multirow{6}{*}{$\begin{array}{l}\text { Spawning capable } \\
(\mathrm{n}=5)\end{array}$} & Left & A & 900 & 131 & 61 & 27 & 9 & - & \multirow[t]{6}{*}{57.0} \\
\hline & & M & 971 & 158 & 70 & 23 & 5 & - & \\
\hline & & $\mathrm{P}$ & 930 & 148 & 91 & 17 & 4 & - & \\
\hline & Right & $\mathrm{A}$ & 894 & 124 & 84 & 32 & 12 & - & \\
\hline & & M & 942 & 138 & 81 & 16 & 5 & - & \\
\hline & & $\mathrm{P}$ & 970 & 131 & 92 & 33 & 1 & - & \\
\hline \multirow{6}{*}{$\begin{array}{l}\text { Actively spawning }{ }^{\mathrm{a}} \\
(\mathrm{n}=6)\end{array}$} & Left & $\mathrm{A}$ & 627 & 112 & 66 & 48 & 30 & 49 & \multirow[t]{6}{*}{68.4} \\
\hline & & M & 696 & 104 & 83 & 46 & 27 & 65 & \\
\hline & & $\mathrm{P}$ & 720 & 94 & 70 & 36 & 26 & 59 & \\
\hline & Right & A & 638 & 93 & 69 & 40 & 35 & 56 & \\
\hline & & M & 653 & 104 & 64 & 45 & 40 & 49 & \\
\hline & & $\mathrm{P}$ & 654 & 107 & 65 & 41 & 25 & 66 & \\
\hline
\end{tabular}

$\mathrm{n}=$ number of females analyzed; ${ }^{\mathrm{a}}=$ reproductive sub-phases; ${ }^{\mathrm{b}}=$ three $3.8 \mathrm{~mm}^{2}$ microscopic fields $\times \mathrm{n} ; \mathrm{A}=$ anterior, $\mathrm{M}=$ middle; $\mathrm{P}=$ posterior; $\mathrm{PG}=$ primary growth oocyte; $\mathrm{CA}=$ cortical alveolar oocyte; $\mathrm{Vtg} 1$ = primary vitellogenic oocyte; $\mathrm{Vtg} 2$ = secondary vitellogenic oocyte; $\mathrm{Vtg} 3=$ tertiary vitellogenic oocyte; $\mathrm{OM}=$ oocyte maturation.

TABLE 2

Chi-square goodness-of-fit test results for oocyte density frequencies in anterior, middle and posterior regions of left and right ovary lobes of Lachnolaimus maximus females in four reproductive phases and sub-phases

\begin{tabular}{|c|c|c|c|c|c|c|c|}
\hline Female reproductive phase & $\mathrm{n}$ & Ovary lobe & $\chi^{2}$ & d.f. & $\mathrm{p}$ & Total oocyte count & Total area analyzed ${ }^{\mathrm{b}}\left(\mathrm{mm}^{2}\right)$ \\
\hline \multirow[t]{2}{*}{ Early developing ${ }^{\mathrm{a}}$} & \multirow[t]{2}{*}{8} & Left & 3.65 & 2 & 0.1610 & 6525 & \multirow{2}{*}{273.6} \\
\hline & & Right & 2.63 & 2 & 0.2683 & 6435 & \\
\hline \multirow[t]{2}{*}{ Developing } & \multirow[t]{2}{*}{4} & Left & 6.57 & 4 & 0.1602 & 2906 & \multirow{2}{*}{136.8} \\
\hline & & Right & 4.04 & 4 & 0.4006 & 2971 & \\
\hline \multirow[t]{2}{*}{ Spawning capable } & \multirow[t]{2}{*}{5} & Left & 12.2 & 8 & 0.1423 & 3545 & \multirow{2}{*}{171.0} \\
\hline & & Right & 19.04 & 8 & $0.0146^{*}$ & 3555 & \\
\hline \multirow[t]{2}{*}{ Actively spawning ${ }^{a}$} & \multirow[t]{2}{*}{6} & Left & 10.65 & 10 & 0.3858 & 2958 & \multirow{2}{*}{205.2} \\
\hline & & Right & 7.42 & 10 & 0.6852 & 2844 & \\
\hline
\end{tabular}

$\mathrm{a}=$ reproductive sub-phases; $\mathrm{n}=$ number of females analyzed; $\chi^{2}=$ chi-square goodness-of-fit statistic; d.f. $=$ degrees of freedom $(\mathrm{r}-1)(\mathrm{c}-1)$, with $\mathrm{r}=$ anterior, middle and posterior regions of each right and left lobes of ovaries, and $\mathrm{c}=$ oocyte stages (see Table1), for a chi-square calculated from contingency table data; $\mathrm{p}=$ probability value; ${ }^{\mathrm{b}}=$ three $3.8 \mathrm{~mm}^{2}$ microscopic fields $\mathrm{x}$ three ovary regions $\mathrm{x} n . *$ significant statistical difference $(\mathrm{P}<0.05)$.

of the right lobe $\left(\chi^{2}=7.83 ;\right.$ d.f. $=6 ; \mathrm{P}=$ 0.2510 ). Oocyte frequency distribution between lobes was essentially uniform, no matter the reproductive phase or sub-phase $\left(\chi^{2}, 0.1459\right.$ $\leq \mathrm{P} \leq$ 0.7094; Table 4).

\section{DISCUSSION}

Most of females analyzed in the present study exhibited a high degree of homogeneity in oocyte distribution within and between the ovary lobes. The only observed difference in distribution was between different regions of the right lobe in SC phase females. These females had low Vtg3 oocyte densities in both lobes, as well as notable variation in the frequencies of this oocyte stage among the regions of the right lobe. This variation was apparently one of the possible factors causing the heterogeneity observed in the SC phase females. During the spawning season of $L$. maximus from the Eastern Gulf of Mexico, Collins and McBride (2015) observed a diel pattern of oocyte maturation in females: germinal vesicle migration 
TABLE 3

Replicated goodness-of-fit test (heterogeneity G-test) results for oocyte density frequencies in anterior, middle and posterior regions of the right ovary lobe of five Lachnolaimus maximus females in spawning capable $(\mathrm{SC})$ reproductive phase. Total area analyzed $=57.0 \mathrm{~mm}^{2}$

\begin{tabular}{|c|c|c|c|c|c|c|c|c|c|c|}
\hline \multirow{2}{*}{ Ovary region } & \multicolumn{6}{|c|}{ Total oocyte counts } & \multirow{2}{*}{ Test } & \multirow{2}{*}{ G } & \multirow{2}{*}{ d.f. } & \multirow[b]{2}{*}{$\mathrm{p}$} \\
\hline & PG & $\mathrm{CA}$ & Vtg1 & Vtg2 & $\operatorname{Vtg} 3$ & $\mathrm{OM}$ & & & & \\
\hline Anterior & 894 & 124 & 84 & 32 & 12 & - & & 1915.88 & 4 & $0.0001 *$ \\
\hline Middle & 942 & 138 & 81 & 16 & 5 & - & & 2157.78 & 4 & $0.0001 *$ \\
\hline \multirow[t]{2}{*}{ Posterior } & 970 & 131 & 92 & 33 & 1 & - & & 2177.94 & 4 & $0.0001 *$ \\
\hline & & & & & & & Total G & 6251.60 & 12 & $<0.05$ \\
\hline \multirow[t]{2}{*}{ Pooled } & 2806 & 393 & 257 & 81 & 18 & - & Pooled G & 6231.11 & 4 & $<0.05$ \\
\hline & & & & & & & Heterogeneity $\mathrm{G}$ & 20.49 & 8 & 0.0086 \\
\hline
\end{tabular}

$\mathrm{PG}=$ primary growth oocyte; $\mathrm{CA}=$ cortical alveolar oocyte; $\mathrm{Vtg} 1=$ primary vitellogenic oocyte; $\mathrm{Vtg} 2=\operatorname{secondary}$ vitellogenic oocyte; $\mathrm{Vtg} 3$ = tertiary vitellogenic oocyte; $\mathrm{OM}=$ oocyte maturation; $\mathrm{G}=\mathrm{G}$ statistic; d.f. = degrees of freedom; $\mathrm{p}=$ probability value; $*$ = highly significant statistical difference $(\mathrm{P}<0.05)$.

TABLE 4

Chi-square goodness-of-fit test results for oocyte density frequencies in left and right ovary lobes of Lachnolaimus maximus females in four reproductive phases and sub-phases

\begin{tabular}{lcccccc}
\multicolumn{1}{c}{ Female reproductive phase } & $\mathrm{n}$ & $\chi^{2}$ & d.f. & $\mathrm{p}$ & Total oocyte counts & Total area analyzed ${ }^{\mathrm{b}}\left(\mathrm{mm}^{2}\right)$ \\
Early developing $^{\mathrm{a}}$ & 8 & 0.60 & 1 & 0.4390 & 12960 & 547.2 \\
Developing & 4 & 3.85 & 2 & 0.1459 & 5877 & 273.6 \\
Spawning capable & 5 & 6.20 & 4 & 0.1844 & 7100 & 342.0 \\
Actively spawning $^{\mathrm{a}}$ & 6 & 2.94 & 5 & 0.7094 & 5802 & 410.4 \\
\hline
\end{tabular}

$\mathrm{a}=$ reproductive sub-phases; $\mathrm{n}=$ number of females analyzed; $\chi^{2}=$ chi-square goodness-of-fit statistic; d.f. $=$ degrees of freedom ( $\mathrm{r}-1)(\mathrm{c}-1)$, with $\mathrm{r}=$ left or right lobes of the ovaries, and $\mathrm{c}=$ oocytes stages (see Table 1$), \mathrm{p}=$ probability value; ${ }^{\mathrm{b}}=$ three $3.8 \mathrm{~mm}^{2}$ microscopic fields $\mathrm{x}$ three ovary regions $\mathrm{x}$ two lobes $\mathrm{x} \mathrm{n}$.

of the vitellogenic oocytes occurs in the late morning-early afternoon preceding spawning day. As a consequence, few vitellogenic oocytes without any evidence of maturation were present in the ovaries at mid-day. Notwithstanding, SC phase females analyzed in the present study presented neither oocytes undergoing early nor late germinal vesicle migration. These females were not undergoing $\mathrm{OM}$ and probably were barely entering the SC phase and therefore displaying very few oocytes progressing towards the final vitellogenesis stage.

In this latter case, then females classified as being in the SC phase, may not necessarily be representative of this stage, and data from them must be used with caution. Larger sample sizes of SC phase females collected throughout this species' reproductive season would help to eliminate any uncertainty about Vtg3 oocyte distribution during this phase. However, even if $\mathrm{Vtg} 3$ oocyte distribution is heterogeneous in the right lobe during this phase, it did not affect the protocol for estimating fecundity. Female $L$. maximus have asynchronous oocyte development and engage in successive batch spawning (Claro et al., 1989; McBride \& Johnson, 2007). This means that only females in the AS subphase, not exhibiting newly collapsed POFs in the ovary, should be selected to estimate batch fecundity (Murua et al., 2003). In the present data, AS sub-phase females exhibited a homogeneous distribution of all oocyte stages, including OM, which are those considered when estimating batch fecundity.

Two previous studies have been done on oocyte development homogeneity in $L$. maximus, both with a Florida population (Davis, 1976; McBride \& Johnson, 2007). 
Over 40 years ago, Davis (1976) has addressed oocyte development in the anterior, middle and posterior regions of the same lobe and between right and left lobes. Using contingency tables based on the frequency distributions and supported with $\chi^{2}$ data, this author analyzed if the distribution of oocytes in three diameter ranges differed between regions of the same lobe and/or between lobes. No differences were observed in oocyte counts in any of the three diameter classes between regions or lobes. However, this analysis was not particularly robust since the sample size was small $(\mathrm{N}=$ 2; 29.6 and $30.4 \mathrm{~cm} \mathrm{FL),} \mathrm{and} \mathrm{the} \mathrm{oocyte} \mathrm{dia-}$ meter ranges were unrelated to reproductive phase, being essentially random. McBride and Johnson (2007) also studied histological sections from three sections of ovary lobes in $L$. maximus, and found no differences in oocyte distribution. However, these authors reached their conclusion by analyzing the oocytes stages present, tunica appearance, and presence or absence of atretic, rather than attempting to count cell numbers per stage, as was done in the present study (McBride, personal communication, May 19, 2016).

Oocyte distribution patterns in teleosts vary by species, and appear unrelated to taxonomic level or any other ecological or biogeographic characteristic. The pattern in $L$. maximus of largely homogeneous distribution of oocyte stages within and between ovary lobes coincides with reports for other females teleosts. It has been observed in species from both temperate waters [e.g. Clupea harengus (Linnaeus, 1758) (Ma et al., 1998), Spicara maena (Linnaeus, 1758) (Matić-Skoko et al., 2004), Gadus morhua and Merluccius merluccius (Linnaeus, 1758) (Witthames et al., 2009), Epinephelus marginatus (Lowe, 1834) (Reñones et al., 2010), and Pseudopleuronectes americanus (Walbaum, 1792) (McElroy et al., 2013)]; tropical and subtropical waters [e.g. Chaetodon multicinctus (Garrett, 1863) (Tricas \& Hiramoto, 1989), Leiognathus equulus (Forsskål, 1775) (Lee et al., 2005), Spratelloides gracilis (Temminck, \& Schlegel, 1846)
(Weng et al., 2005), Tylosurus acus melanotus (Bleeker, 1850) (Liao \& Chang, 2011), and Psenopsis anomala (Temminck, \& Schlegel, 1844) (Wu et al., 2012)]; and temperate and tropical waters [e.g. Helicolenus dactylopterus (Delaroche, 1809) (Sequeira et al., 2012) and Trachinocephalus myops (Forster, 1801) (Yang et al., 2013)]. In contrast, other teleosts exhibit a heterogeneous oocyte distribution pattern in the ovary, as in the temperate marine flatfish species Solea solea (Linnaeus, 1758) (Witthames \& Greer Walker, 1995), Limanda aspera (Pallas, 1814) (Nichol \& Acuna, 2001) and Pleuronectes platessa (Linnaeus, 1758) (Kennedy et al., 2007), and the freshwater species Prochilodus lineatus (Valenciennes, 1837) from Brazil (Hainfellner et al., 2011). In another example, significant differences in average oocyte size were observed along the anterior-posterior axis and between the center and periphery of ovary lobes in bigeye tuna Parathunnus sibi (= Thunnus obesus; Lowe, 1839) (Yuen, 1955) and bluefin tuna Thunnus thynnus (Linnaeus, 1758) (Baglin, 1982).

Given the homogeneous oocyte distribution pattern within and between the ovary lobes in L. maximus females in the AS sub-phase, no systematization is required of the gonad histological sampling protocol to estimate species batch fecundity. Stereological methods in tandem with digital image processing can therefore be used to make accurate measurements of oocyte size, shape, count, area and volume in the ovaries of L. maximus, and generate unbiased fecundity estimates in this species. However, ovary sampling for characterizing the reproductive cycle in this species, based on analysis of the seasonal development of reproductive phase and sub-phase frequency, needs to be done with caution due to the potential for heterogeneity among Vtg3 oocytes in the right ovary lobe of females in the SC phase. If this is a possible risk in a given sample, the present results suggest it is best to systematically take sections of any region in the left ovary when conducting a study encompassing all of a species' reproductive aspects. 


\section{ACKNOWLEDGMENTS}

Collections were authorized by fishing licenses: PPF/DGOPA-037/14 and PPF/ DGOPA-080/15, from Secretaría de Agricultura, Ganadería, Desarrollo Rural, Pesca y Alimentación/Comisión Nacional de Acuacultura y Pesca. The authors thank the professional fishers Leonardo Pech, Santos Efraín Sosa Pech, José Nicolás Flores Aceves, Luis Emilio Aceves Nadal and Cesar Alexander Tun Pacheco for their assistance with sample collection. We also thank the fishing cooperatives Nohoch Cuch S.C.L., S.C.P.P., and Pescadores de Río Lagartos S.C.D.R.L, S.C.P.P. The Consejo Nacional de Ciencia y Tecnología (CONACYT) financed a doctoral research stay in La Paz, Baja California Sur through the 2013 PNPC RM program. Technical assistance with gonad histological processing was provided by Teresa Colás-Marrufo, and the digital images were taken by Ximena Renán. We thank R. $\mathrm{S}$. McBride, one anonymous reviewer and the editor for providing insightful comments that improved the quality of the manuscript.

\section{RESUMEN}

La distribución de los ovocitos en y entre los lóbulos ováricos de Lachnolaimus maximus (Perciformes: Labridae) es generalmente homogénea. Para el estudio de la reproducción de los peces es necesario, un conocimiento previo sobre la distribución de los ovocitos en el ovario, así como estimaciones cuantitativas del número de ovocitos para estimar la fecundidad por lote o anual. Una distribución heterogénea exige tener un protocolo de muestreo estandarizado para prevenir sesgos en las estimaciones, mientras que una distribución homogénea permite utilizar muestras de cualquier parte de las gónadas sin riesgo de sesgo. Nosotros estudiamos el patrón de distribución de los ovocitos de la población de la doncella de pluma Lachnolaimus maximus del sur del Golfo de México. Para este propósito, 23 hembras maduras fueron seleccionadas de un total de 47 individuos que presentaron ovocitos observables a simple vista en los ovarios. Estas hembras fueron clasificadas según su fase o sub-fase reproductiva (desarrollo temprano-DT, desarrollo-D, aptitud para desovar-AD y desove activo-DA). Seis secciones histológicas fueron realizadas de las regiones anterior, media y posterior de los lóbulos derecho e izquierdo del ovario de cada individuo. Un procesamiento digital de imágenes (AxioVision e Image ProPlus) fue utilizado para estimar la densidad de los ovocitos, en diferentes estadios de desarro1lo, por unidad de área. Las frecuencias de distribución de los ovocitos fueron analizadas entre regiones de un mismo lóbulo y entre lóbulos de cada ovario por medio de tablas de contingencia. Este análisis involucró la aplicación de la prueba de bondad de ajuste del $\chi^{2}$ de Pearson y de la prueba de $\mathrm{G}$ replicada en el caso de observar una distribución heterogénea. La mayoría de las 23 hembras analizadas presentó una distribución homogénea de los diferentes estadios de ovocito, en cualquier lóbulo considerado. En el lóbulo ovárico izquierdo, la distribución de los ovocitos fue similar en las tres regiones muestreadas, en cualquier fase o sub-fase de las hembras. En el lóbulo ovárico derecho, las frecuencias de los ovocitos fueron semejantes para las hembras en fase y sub-fases de DT, D y DA; sin embargo, durante la sub-fase de $\mathrm{AD}$, una heterogeneidad en el desarrollo de los ovocitos en vitelogénesis terciaria-Vtg3 fue observada, especialmente en las muestras de las regiones media y posterior de este lóbulo. Las hembras en sub-fase de DA son usualmente utilizadas para estimar la fecundidad por lote en las especies de peces como L. maximus, la cual presenta un desarrollo asincrónico de los ovocitos y realiza desoves sucesivos por lote. Debido al patrón de distribución homogéneo de los ovocitos en y entre los lóbulos ováricos de las hembras en sub-fase de DA, no se requiere estandarizar un protocolo de muestreo histológico de las gónadas para estimar la fecundidad por lote de la especie. Sin embargo, debido a la distribución heterogénea de los ovocitos en Vtg3 en el lóbulo ovárico derecho de las hembras en fase de DA, es preferible tomar sistemáticamente secciones de cualquier región del lóbulo ovárico izquierdo cuando se realiza un estudio que incluye todo los aspectos reproductivos de la especie.

Palabras clave: reproducción, homogeneidad del ovario, doncella de pluma, Golfo de México.

\section{REFERENCES}

Baglin, Jr., R. E. (1982). Reproductive biology of western Atlantic bluefin tuna. Fishery Bulletin, 80, 121-134

Brown-Peterson, N., Thomas, P., \& Arnold, C. (1988). Reproductive biology of the spotted seatrout, Cynoscion nebulosus, in south Texas. Fishery Bulletin, 86, 373-388.

Brown-Peterson, N., Wyanski, D., Saborido-Rey, F., Macewicz, B., \& Lowerre-Barbieri, S. (2011). A standardized terminology for describing reproductive development in fishes. Marine and Coastal Fisheries: Dynamics, Management, and Ecosystem Science, 3(1), 52-70.

Carpenter, K. E. (2002). The living marine resources of the Western Central Atlantic. Volume 3: Bony fishes part 2 (Opistognathidae to Molidae), sea turtles and marine mammals. FAO Species Identification Guide for Fishery Purposes and American Society 
of ichthyologists and Herpetologists Special Publication No. 5. FAO, Rome.

Claro, R., García-Cagide, A., \& Fernández de Alaiza, R. (1989). Características biológicas del pez perro, Lachnolaimus maximus (Walbaum), en el Golfo de Batabanó, Cuba. Revista Investigaciones del Mar, Cuba, 10(3), 239-252.

Colin, P. L. (1982). Spawning and larval development of the hogfish, Lachnolaimus maximus (Pisces: Labridae). Fishery Bulletin, 4, 853-862.

Collins, A. B., \& McBride, R. S. (2015). Variations in reproductive potential between nearshore and offshore spawning contingents of hogfish in the eastern Gulf of Mexico. Fisheries Management and Ecology, 22, 113-124.

Davis, J. C. (1976). Biology of the hogfish, Lachnolaimus maximus (Walbaum), in the Florida Keys (Master dissertation). University of Miami, Coral Gables, FL.

Di Rienzo, J. A., Casanoves, F., Balzarini, M. G., Gonzalez, L., Tablada, M., \& Robledo, C. W. (2013). Infostat (Versión 2013). Grupo InfoStat, FCA, Universidad Nacional de Córdoba, Argentina. Retrieved from http://www.infostat.com.ar

Gabe, M. (1968). Techniques histologiques. Paris: Masson \& Cie.

Hainfellner, P., de Souza, T. G., Nascimento, T. S. R., Freitas, G. A., \& Batlouni, S. R. (2011). Heterogeneous distribution of oocytes in the ovaries of Prochilodus lineatus. Indian Journal of Science and Technology. Proceedings of $9^{\text {th }}$ International Symposium on Reproductive Physiology of Fish. Cochin India, 4, 111-112.

IUCN (International Union for Conservation of Nature and Natural Resources). (2016). The IUCN Red List of Threatened Species. Version 2015.4. Retrieved from dhttp://www.iucnredlist.org.

Kennedy, J., Witthames, P. R., \& Nash, R. D. M. (2007). The concept of fecundity regulation in plaice (Pleuronectes platessa) tested on three Irish Sea spawning populations. Canadian Journal of Fisheries and Aquatic Sciences, 64, 587-601.

Klibansky, N., \& Juanes, F. (2008). Procedures for efficiently producing high-quality fecundity data on a small budget. Fisheries Research, 89, 84-89.

Lee, C. F., Liu, K. M., Su, W. C., \& Wu, C. C. (2005). Reproductive biology of the common ponyfish Leiognathus equulus in the south-western waters off Taiwan. Fisheries Science, 71, 551-562.

Liao, Y. Y., \& Chang, Y. H. (2011). Reproductive Biology of Needlefish Tylosurus acus melanotus in waters around Hsiao-Liu-Chiu Island, Southwestern Taiwan. Zoological Studies, 50(3), 296-308.
Lowerre-Barbieri, S. K., Henderson, N., Llopiz, J., Walters, S., Bickford, J., \& Muller, R. (2009). Defining a spawning population (spotted seatrout Cynoscion nebulosus) over temporal, spatial, and demographic scales. Marine Ecology Progress Series, 394, 231-245.

Ma, Y., Kjesbu, O. S., \& Jirgensen, T. (1998). Effects of ration on the maturation and fecundity in captive Atlantic herring (Clupea harengus). Canadian Journal of Fisheries and Aquatic Sciences, 55, 900-908.

Matić-Skoko, S., Kraljević, M., \& Dulčić, J. (2004). Fecundity of blotched picarel, Spicara maena L. (Teleostei: Centracanthidae), in the Eastern central Adriatic Sea. Acta Adraiatica, 45(2), 155-162.

McBride, R. S., \& Johnson, M. R. (2007). Sexual development and reproductive seasonality of hogfish (Labridae: Lachnolaimus maximus), an hermaphroditic reef fish. Journal of Fish Biology, 71, 1270-1292.

McBride, R. S., Johnson, M., Bullock, L., \& Stengard, F. (2001). Preliminary observations on the sexual development of hogfish, (Pisces: Labridae). Gulf and Caribbean Fishery Institute Proceedings, 52, 98-102.

McBride, R. S., \& Murphy, M. D. (2003). Current and potential yield per recruit of hogfish, Lachnolaimus maximus, in Florida. Gulf and Caribbean Fishery Institute Proceedings, 54, 513-525.

McBride, R. S., \& Richardson, A. K. (2007). Evidence of size-selective fishing mortality from an age and growth study of hogfish (Labridae: Lachnolaimus maximus), a hermaphroditic reef fish. Bulletin of Marine Science, 80, 401-417.

McBride, R. S., Thurman, P. E., \& Bullock, L. H. (2008). Regional variations of hogfish (Lachnolaimus maximus) life history: consequences for spawning biomass and egg production models. Journal of Northwest Atlantic Fishery Science, 41, 1-12.

McElroy, D. W., Wuenschel, M. J., Press, Y. K., Towle, E. K., \& McBride, R. S. (2013). Differences in female individual reproductive potential among three stocks of winter flounder, Pseudopleuronectes americanus. Journal of Sea Research, 75, 52-61.

Mexicano-Cíntora, G., Leonce-Valencia, C. O., Salas, S., \& Vega-Cendejas, M. E. (2007). Recursos pesqueros de Yucatán: fichas técnicas y referencias bibliográficas. Mérida, Yucatán, México: CINVESTAV-IPN.

Muñoz, R. C., Burton, M. L., Brennan, K. J., \& Parker, O. (2010). Reproduction, habitat utilization, and movements of hogfish (Lachnolaimus maximus) in the Florida keys, U.S.A.: Comparisons from fished versus unfished habitats. Bulletin of Marine Science, 86(1), 93-116.

Murua, H., Kraus, G., Saborido-Rey, F., Witthames, P., Thorsen, A., \& Junquera, S. (2003). Procedures to estimate fecundity of marine fish species in relation 
to their reproductive strategy. Journal of Northwest Atlantic Fishery Science, 33, 33-54.

Nichol, D. G., \& Acuna, E. I. (2001). Annual and batch fecundities of yellowfin sole, Limanda aspera, in the Eastern Bering Sea. Fishery Bulletin, 99, 108-122.

Parker, R. O. (2000). Courtship in hogfish, Lachnolaimus maximus, and other behavior of reef fishes off Beaufort, North Carolina. The Journal of the Elisha Mitchell Scientific Society, 116(3), 260-261.

Pertusa, J. F. (2003). Técnicas de análisis de imagen: Aplicaciones en biología. Universidat de València, Aldaia, Spain.

Reñones, O., Grau, A., Mas, X., Riera, F., \& SaboridoRey, F. (2010). Reproductive pattern of an exploited dusky grouper Epinephelus marginatus (Lowe 1834) (Pisces: Serranidae) population in the western Mediterranean. Scientia Marina, 74(3), 523-537.

Robinson, M. P., \& Prince, J. S. (2003). Morphology of the sperm of two wrasses, Thalassoma Bifasciatum and Lachnolaimus Maximus (Labridae, Perciformes). Bulletin of Marine Science, 72(1), 247-252.

Sequeira, V., Neves, A., Paiva, R. B., Vieira, A. R., \& Gordo, L. S. (2012). Is the fecundity type of the zygoparous fish species Helicolenus Dactylopterus determinate or indeterminate? Vie et Milieu, 62(1), 37-42.

Sokal, R. R., \& Rohlf, J. (1995). Biometry. The principles and practices of statistics in biological research ( $3^{\text {rd }}$ ed.). New York: W. H. Freeman and Company.

Tricas, T. C., \& Hiramoto, J. T. (1989). Sexual differentiation, gonad development, and spawning seasonality of the Hawaiian butterflyfish, Chaetodon multicinctus. Environmental Biology of Fishes, 25, 111-124.
Wallace, R. A., \& Selman, K. (1981). Cellular and dynamic aspects of oocyte growth in teleosts. American Zoologist. Tampa Florida, 21, 325-343.

Weng, J. S., Liu, K. M., Lee, S. C., \& Tsai, W. S. (2005). Reproductive Biology of the Blue Sprat Spratelloides gracilis in the waters around Penghu, Central Taiwan Strait. Zoological Studies, 44(4), 475-486.

Witthames, P. R., \& Greer Walker, M. (1995). Determinacy of fecundity and oocyte atresia in sole (Solea solea) from the Channel, the North Sea and the Irish Sea. Aquatic Living Resources, 8, 91-109.

Witthames, P. R., Thorsen, A., Murua, H., Saborido-Rey, F., Greenwood, L. N., Dominguez, R., \& Kjesbu, O. S. (2009). Advances in methods for determining fecundity: application of the new methods to some marine fishes. Fishery Bulletin, 107, 148-164.

Wootton, J. R., \& Smith, C. (2015). Reproductive biology of teleost fishes. Oxford: Wiley Blackwell.

Wu, C. C., Su, W. C., Liu, K. M., Weng, J. S., \& Wu, L. J. (2012). Reproductive Biology of the Japanese butterfish, Psenopsis anomala, in the waters off southwestern Taiwan. Journal of Applied Ichthyology, 28, 209-216.

Yang, J. L., Chen, L. H., \& Hu, T. J. (2013). Maturity and spawning of painted lizardfish, Trachinocephalus myops (Bloch and Schneider, 1801) in the southeastern China Sea. Journal of Applied Ichthyology, 29, 1050-1055.

Yuen, H. S. H. (1955). Maturity and fecundity of bigeye tuna in the Pacific. Special Scientific Report: Fisheries (No. 150, pp. 1-30). Washington: United States of Department of the Interior, Fish and Widlife Service. 
